\title{
Bruno Latour and the myth of autonomous academic discipline: Rethinking education in the light of various modes of existence
}

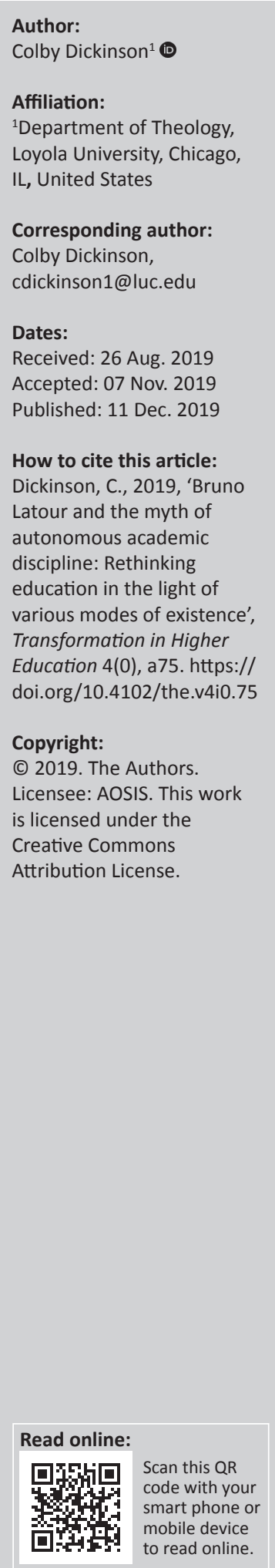

Background: Issues of identity, interdependence, relationality and violence are far larger than the human species alone, although humanity has often pretended as if it alone were the beneficiaries of studying such ideas.

Aim: Pedagogically, the complexity of existence beyond human being must influence the traditional humanities curriculum or risk further isolation and alienation within humanitydominant narratives.

Setting: As climate change continues to alter our comprehension of what is truly at stake in the survival of life on this planet, however, humankind needs a complete rethinking of its relationship with the multiple forms of life that dwell alongside it, as well as the traditional division between the humanities and the sciences within academic settings.

Methods: It is with this scenario before us that I turn to the work of Bruno Latour who reconceives of humanity's relationship with nature as an interdisciplinary and boundarycrossing project, one that has deep pedagogical implications.

Results: I demonstrate how Latour's collaborative and highly original work ranges across disciplines and provides new ways to contemplate research in academia.

Conclusion: Latour's thought moves beyond polarising anti-humanist language and towards a way to limit the sovereign claims of humanity, opening discourse towards other non-human participants.

Keywords: Bruno Latour; complexity; modes of existence; interdisciplinary; non-human participants.

\section{Introduction}

The human sphere rises by pushing back its own animal premise. Being human means the acquired inability to remain an animal. In metaphysical terms, this yields the thesis that we are on the island of the idea, whose infinite nature pushes the finitude of empirical environments to the background. This would make the infinite an enclave within finite circumstances. It would gape open like an abyss directed upwards, as an interruption of life required to bear a vision of that which is more than life. Whoever can understand that may do so. However one puts it: the space islands of humans are forward-deployed posts against the open. (Sloterdijk 2016:460)

For, perhaps, the entirety of its history, humanity has established itself over and against the rest of existence, mainly against other animals, certainly against the plant life, microbes and inanimate matter that make up the rest of existence on this planet. Humankind's ability to dominate over nature has in fact characterised its definition of itself. In this 'interruption of life' brought about in order to secure humanity its place amongst the infinite, as Sloterdijk (2016) has phrased matters above, a metaphysics is conceived as that which legitimates, not so much the existence of any divine being per se, but of the human being itself. The space of 'the open', as Rilke had once termed it and as Heidegger later appropriated it in his own analysis of the border between the human and the animal, is really a site of negotiation and contestation wherein the human being comes to face its own image, and perhaps to see it deconstructed before its very eyes. ${ }^{1}$

As part of its confrontation with humanity and its history, modern humanist thought gave way in the early to mid-20th century to less anthropocentric dimensions of critical inquiry, what some

1.See, amongst others, the relevant remarks made in both Derrida (2008) and Agamben (2004). In the context of contemporary philosophical reconsiderations of human being and its relation to ecology, see Wood (2005) as well as his more recent Re-occupy earth: Notes toward an Other beginning (Wood 2019). 
considered to be a form of anti-humanism. ${ }^{2}$ Though such a stance certainly contains within it the possibility of repealing longstanding definitions of the human being - and so likewise risks establishing positions that might be deemed inhuman at times - what such positions ultimately reveal to us are the limitations of seeing the world through purely human eyes and so from an extremely limited and solely human perspective. Although such anthropocentric views are readily questioned today, the impact that this rethinking has upon education and learning has yet to be more thoroughly exhausted.

Pedagogically, and in terms that need to ripple through an academic context more often bent on either diminishing or exalting the humanities, we have not really begun to lessen the hold of such an anthropocentric perspective in the classroom or in terms of curriculum development, while at the same time retaining something of its importance. So many fields within the humanities - history, politics, economics, psychology, sociology, anthropology, languages and literatures, not to mention theology - have been almost entirely reliant upon the focal point of the human being, a remnant of humanity's long struggle with itself and its own understanding. This very limited point of view, however, and as voices in the sciences often remind us, is drawing to a close. ${ }^{3}$

So much anxiety surrounds the possible death of the humanities in its contemporary struggle with the relevance (and funding) of the sciences. However, perhaps the problem is not the potential irrelevance of the humanities, but rather the failure of the humanities to open up to life lived beyond the very limited perspective of humanity (Felski 2016:215-229). ${ }^{4}$ The life that seemed to be larger than the physical, empirical life surrounding it - what Sloterdijk (2016) marked as the entrance of metaphysics and its myriad justifications for humanity's dominance over everything else in our world - needs to be brought down to the level of simply life itself, of but one of the other life forms that occupy the world in which we live. ${ }^{5}$

Issues of identity, interdependence, relationality and violence, amongst so many others, are far larger than the human species alone, though humanity has frequently pretended as if it alone were the beneficiaries of studying such ideas. As the increasingly drastic realities of climate change continue to alter our comprehension of what is truly at stake in the survival of life on this planet, humankind is, however, desperately in need of a complete rethinking of its relationship to the multiple forms of life that dwell with it as well as the traditional division between the humanities and the sciences

2 See the historical narrative unfolded in Geroulanos (2010).

3.See the arguments presented in, amongst others, Touya de Marenne (2016)

4.These reflections are, in part, inspired by the issue of New Literary History devoted to the question of humanities in the light of the work of Bruno Latour specifically.

5.The decline of metaphysics in the modern era and the accompanying rise of atheism and secularity have provided a focus upon humanity, but one sphere of a much more comp and liverse existence thas surrounds it at the same time as this realisation also and un also opens up an increased stress upon a life lived without metaphysical supports just another life amidst many other lives. See, for example, the argument for atheism made in this context in Hägglund (2019). For more political theological responses to climate change, see, amongst others, Keller (2018) and Northcott (2013). within academic and university settings. Regarding pedagogy, and as should become clear in what follows, more of the complexity of existence beyond the human being must be brought to bear upon the traditional humanities curriculum or the risk of further isolation and alienation might spell a catastrophic end to human civilisation.

It is with this impending and admittedly apocalyptic scenario before us that I want to look at the work of Bruno Latour which, more recently, re-conceives of humanity's relationship to nature as an interdisciplinary and boundary-crossing project, one that has deep pedagogical implications that, I argue, we must learn to embrace more fully. This is not to suggest that Latour's work is the first or the most comprehensive account of the need to make such movements in academic discourse. His collaborative work across various unique disciplines and perspectives from the philosophy of science to the limits of religious discourse - however, provides new ways to contemplate research in an academic setting, and in a way that fully dovetails with ongoing work in ecological, ecofeminist and critical theoretical fields. In what follows, I want to introduce and examine some of the implications of his philosophical thought as it moves beyond polarising anti-humanist language and towards a way to limit the sovereign claims of humanity, opening discourse up towards other, non-human participants in ways that we have only just begun to consider. It is my hope that this introduction to Latour's work within a pedagogical perspective might yield some fruitful points of mutual engagement for those already working in similar territory.

\section{Learning to see beyond the limits of humanity}

According to Latour (2013b):

Nothing prevents readers who have now become coinvestigators from proposing to restitute experiences and link values in ways that differ completely from my own. (p. 480)

As numerous voices make clear to us nearly every day, humanity has long neglected to take seriously the complex relationships, environments, biospheres and ecosystems that have been functioning on this planet long before humanity, only relatively recently, ascended to the top of a selfconstructed pyramid asserting its own dominance. Humanity has, and certainly continues, to define itself according to an elaborate series of identities, properties, possessions, representations and capacities that are, viewed from the perspective of those abundant natural phenomena that far exceed the population of humanity, quite limited. Yet the society and normative order we have created, including all of the social, linguistic, legal, juridical, political, religious and economic markers that comprise most human affairs, sets an exceedingly narrow vision of who has the right to speak within such a context, indeed who even has anything like legal rights at all.

From the beginning, then, we must recognise how the academic classroom is inherently confined and conditioned 
to limit its participants to those alone who have set boundaries in advance for what types of speech will and will not be allowed. What is missed, omitted, marginalised or otherwise excluded from this conversation is so numerous, however, as to almost render the entire enterprise of education superfluous before it begins - a point that a good many 'practical' learners who have found traditional education to be less than to their liking have doubtlessly noted for centuries.

It is consequently no surprise that the popular imagination permeating our world today is full of those apocalyptic images that signal the limitations of human existence, from post-apocalyptic zombie scenarios to imagined worlds where disease has rendered life nearly impossible, from a planet that can no longer reproduce children to another one where unleashed natural disasters or monstrous creatures upend all normative daily life. These suggestive images go some ways towards explaining the success of Weisman's (2007) The world without us, a realistic, scientific look at what would happen to our world should humankind suddenly stop existing. This disaster scenario - from a human point of view at least - may have at one time seemed rather pessimistic or bleak, though it has increasingly begun to take up a certain space more squarely within a popular consciousness that knows how something about human existence as it is currently configured is strangely amiss.

Powers' (2018) Pulitzer Prize-winning novel The overstory about the world of trees and nature conflicting with a decidedly human-financial agenda points us in much the same direction, though it also underscores the fundamental problem with trying to rethink humanity's relationship with other, non-human actors who traditionally have no rights and so no place within political and economic discussions. As one of his characters, a copyright and patent lawyer, reflects at one point upon a legal proposal that would grant rights to non-human things, such as trees (Powers 2018):

The proposal is bound to sound odd or frightening or laughable. This is partly because until the rightless thing receives its rights, we cannot see it as anything but a thing for the use of 'us' - those who are holding rights at the time. (p. 250)

As he eventually goes on to consider corporations, universities, states and infants all have lawyers who represent them, so why cannot other non-human things?

What is it within us that gives us this need not just to satisfy basic biological wants, but to extend our wills over things, to objectify them, to make them ours, to manipulate them, to keep them at a psychic distance? (Powers 2018:250-251)

The implicit answer, of course, is that a psychic distance is necessary in order to assert dominance over a 'thing', or whatever is defined as 'less than human' and so devoid of the rights that are granted only to those things we have chosen to bestow with dignity. Humanity's often extremely limited coordinates used to determine the worth of valid and invalid representations depend upon utterly precarious constructs needing to be critically called into question. This is precisely where the philosophy of Latour becomes of critical interest to us, as he repeatedly points beyond what lays before our eyes in order to see a much more complicated, but also realistic, world of varied and multiple modes of existence.

As an example of such limitations, we might note, for example, and as Latour most certainly does, the ways in which humanity has become overly reliant upon those facile dualisms that structure our world in hegemonic fashion. ${ }^{6}$ The restrictions of ancient and modern dualistic categories raw/cooked, sacred/profane, real/constructed, mind/body, conservative/liberal, transcendence/immanence, nature/ nurture, freedom/predetermined, heaven/hell, master/ slave, friend/enemy and so onto the limits of all human forms of speech - are surpassed by the various modes of existence that go far beyond these overly simplistic renderings and which interact in various and diverse ways (Latour 2013b:146). As Latour (2013b:458) himself describes these relationships in his monumental study An inquiry into modes of existence, the interactions between these modes some of which include religion, law, politics, fiction, technology and morality - make a movement away from a monolithic vision of each mode of existence, signalling their intertwined existence as well as presenting a lesson in how everything must learn to inhabit a multi-verse and not a singular universe that dictates a singular logic or a singular morality which only comes, for its part, to fear any semblance of plurality or relativism.

According to the multifaceted logic that Latour espouses, there is no mystery within existence other than the recognition that there are multiple other modes and agents involved in the construction of any given perspective, expressing in their totality a situation that appears to obscure or veil what can be known about a thing, but which really issues a call to show more compassion and understanding for the complexity of existence itself. As Latour (2013) himself describes this almost mystical state of material existence:

This impression that there is always something more than what is known in the thing known does not refer at all to the unknowable [...] but to the presence of other modes whose equal dignity epistemology, despite all its efforts, has never allowed to be recognized. (p. 85, emphasis in the original)

If only humanity would look deeper into whatever perspective or phenomenon we see, he implores, we might be able to comprehend better some of the many factors that are at work in making this only apparent singularity what it is for us within a given context.

Not being able to sense the complexity of a given 'object' (which is really always a subject in its own right), we are typically left with a mistaken impression of a thing's identity, as if it were able to exist on its own, as something possessable, fixed and determined. We thereby fall headlong into a category mistake that is so commonly made as to be 6.l am drawn here to the work of Antonio Gramsci and his analysis of dualistic thought in the context of hegemonic political forms. See Anderson (2017). 
misunderstood as the normative measure (Latour 2013a).? From Latour's (2013b:17) point of view, judging one mode of existence with the veridiction criteria of another mode something that happens a good deal of the time and which only further obscures our detection of those forces working necessarily in unison with each other - frequently results in numerous tensions that might otherwise be dispelled if they were only more properly understood. For example, the criteria used in the realm of politics to determine veracity is quite often thrust upon religion, or the criteria used in legal matters is assumed to be appropriate for moral decisions, creating impasses and conflict where none was necessarily inherent to a given reality. Though it is certainly the case that any particular mode is invested in relationships with other modes, the moment they intersect in an embodied agent or event, each mode also provides a unique window into the operations of whatever is transpiring at a specific moment, what Latour calls a process of 'veridiction' for that particular mode. In his words (Latour 2013b):

A mode of existence is thus always both a version of being-asother (a debiting of discontinuity and continuity, difference and repetition, otherness and sameness) and also its own regime of veridiction. (p. 183)

Taking the time to understand each mode of existence and its various manners of operating can therefore go some way towards defusing potentially confusing situations, as well as clear a path towards other modes of existence that had previously been neglected within a given context.

The possibility of hearing voices that had been marginalised or suppressed beforehand is dependent upon our ability to open humanity towards understanding how such interactions, overlaps and distinctions between modes actually work in a given, and always unique, context. And though each mode has its own procedures for securing veracity, no single mode functions in complete isolation from another, giving us a much fuller picture of reality than we could ever hope to represent in language. There is always a call for witnessing to how more complexity is at stake in assessing reality, even if reality itself cannot be representationally exhausted.

\section{Listening to the voices of the social}

Seeing better how the various modes of existence function together allows us moreover to gain a new perspective entirely on the domain of the social. The 'social', as humanity has traditionally conceived it, is really, according to Latour (2013b:280, 296), 'the concatenation of all the modes' whose unity can no longer be guaranteed by a human institution. It is a complex tapestry of alterity and multiplicity that could be of great benefit precisely when humanity does not attempt to override its plurality and difference through the imposition of a sense of continuity offered through arguments involving essentialist configurations of substance and nature (Latour 7.Latour gives us a brilliant insight into such categorical mistakes as those that lie
between religion and science in his extended essay Rejoicing: Or the torments of religious speech. 2013b:279). The domain of the social must be left to its own processes and dynamics, he argues, and not brought under the veridiction criteria of one mode only, as certain political and religious formulations have been tempted over the course of history to do.

It is in this sense that Latour (2018:12-13) acknowledges how globalisation should imply a multiplication of viewpoints, not their restriction under a particular universal heading. A totalitarian state or all-encompassing religious world view is not the path towards which the social walks, and though his embrace of a pluralistic interaction of modes may sound at times like a capitalist, free-market enterprise, this is the reality of what lies at the heart of the state of being-as-other that ceaselessly involves the mini-transcendence of alteration' (Latour 2013b:254). The goal, as Latour (2013b:203) describes it, is one of imploring a maximum of transformations and embracing metamorphosis as a process so that 'everything can, everything must, become something else.' It is in this sense that Latour's philosophy extends the philosophy of seeing 'oneself as another' into new realms beyond the self/other division. ${ }^{8}$

As one might also surmise from these suggestions, resisting the desire to provide order 'too quickly' to the complex realities around us - the very stuff of reductive representations becomes the maxim that drives Latour's (2013b:401) analysis of the various modes of existence and their interactions. It is these creative fictions we weave together through the interactions of law, politics, religion and the like that are what make the domains of politics, religion and law possible in the first place (Latour 2013b:249). Trying to disentangle them completely from one another in order to make discrete categorical distinctions may be helpful for focusing one's view in a very narrow sense (and such efforts should certainly not be discouraged), but such efforts are ultimately something that must be linked up with other modes in order to recognise the sheer complexity of modes and interactions actually at play in a given context. This is a task involving interpolations, amalgamations, syncretism and harmonics, or, more simply, the recognition that such tasks were always already happening throughout the many worlds inhabited on this planet throughout history (Latour 2013b:304). Though these endeavours may never be exhaustively catalogued or fully understood, this fact in no way reduces the need to strive for such complete comprehension (a task akin to the sociologist Pierre Bourdieu's efforts to always 'objectify objectivity').

Although his categories are mainly dependent upon humanity's perspective on itself and its world, it becomes clear fairly soon in his analysis that what he is ultimately aiming for goes far beyond the limitations that humanity has placed upon itself. Insanity, Latour (2013b:301) counters, for example, is produced only by the myth of autonomy - a modern claim advanced by almost every academic discipline that asserts its own methods and knowledges to assert its 8.See how this theme is also developed in the philosophy of Ricoeur (1995), specifically in his Oneself as Another. 
sovereign descriptive claims over reality. This point is duplicated at another higher level when we simply apply it to humanity in relation to the rest of the world as a whole, something which Latour certainly endorses in his work. And this point is one that we would be well advised to pay particular attention to as well, for the way in which fragmented academic discourses proceed is by imagining that one discipline's account of reality suffices for an exhaustive description of that reality, when it is rather a highly limited perspective that, historically at least, fails to account for perspectives beyond those asserted by humanity. As Latour (2013b:298) himself notes, the problem with religion historically was that it, as a single mode of existence, feigned to 'take responsibility for all domains - politics, morality, art, the cosmos, law, even the economy.' Religion's reductive gestures were enough, at least historically at certain points in time, to displace other (sovereign) claims and to elevate itself as the sole arbiter of knowledge at the same time. This problem, however, was not just that of religion but that of humanity as a whole as it sought to elevate itself above all of the other existences that occupy and dwell within this planet. With such thoughts, we are returned to Sloterdijk's (2016) insistence that metaphysics began with humanity's attempts to exceed the forms of life situated all around it.

Such an example of religion's justifications for dominance, I would highlight as well, does little more than beg the question of how a single disciplinary domain or field of inquiry might attempt to do the same in a contemporary setting, providing reductive explanations, for instance, of complex and multifaceted phenomena, not to mention how the entire educational edifice of the humanities still bears the imprint of a reductively oriented humanity in the very way it is structured within universities and their discourses. The traditional ploys for sovereign power, as embodied in a monolithic perspective that attempts to describe all of reality from its singular point of view - the 'objective', 'God's eye' angle - are only furthered through particular disciplinary observations and the anthropocentrism of university academics on the whole. Embedded within such 'expert' opinions are formulations of subjectivity indebted to uniquely modern claims to sovereignty that have been roundly critiqued but which still maintain a hegemonic hold over the institutions and identities that govern academic discourse. It is from this point of view that Latour's steadfast critiques of the subject/object dichotomy are most needed.

When Latour therefore suggests that just as humanity once had to invent the fiction of sovereignty in order to introduce a new political paradigm, so too do we have the opportunity as well to invent a new way of performing politics beyond the old fictions that have carried us this far. Accordingly, we are right to extend an analogy from political forms of sovereign power into the realm of university discourse and academic disciplines in order to challenge the ways in which the professorial voice or the voice of the researcher is articulated, maintained and defended as a sovereign subject currently in need of displacing or at times perhaps replacing altogether (Latour 2017:263). Though there is nothing new to such revaluations as these insights have characterised educational theory for quite some time now, there is still the ongoing quest to understand what new forms of education might supplant those models of expertise and knowledgeaccumulation that have dominated modern pedagogical discourse. There is still to be heard the many other voices that surround humanity but which, until now, have not been allowed a place at the table where the main conversation about the fate of our planet is being had. We might think, for example, what a curriculum might be like if academics were less inclined to centralise historically metaphysically laden disciplines (e.g. the significance of religion, wars, Eurocentric male political actors and so forth) and more inclined to study ecosystems, migration patterns, human - animal interactions, the 'poetry' (symmetry) of nature and so on.

Beyond this highly suggestive formulation of things, the true pedagogical revolution occurs when Latour contemplates new forms of political association that disseminate sovereign power into multiple locations, causing it to be no longer the sole possession of humanity. It is here that a complete rethinking of democracy takes place. ${ }^{9}$ Latour's (1993:142145) introduction of what he terms a 'parliament of things', where traditional anthropocentric models of sovereign power are challenged and restricted based on the sovereignty of other claims, such as those of the animal world, the natural environment, air and water and so forth, becomes a prime illustration of how disciplinary associations, for example, might be reformulated along these very same lines of thought. As he describes the limitations imposed upon any one particular agent in a recent study of the fate of our planet (Latour 2017):

[I]f one party is capable of taking the territory of another because that other is already occupying, invading, or restricting it, then that party will be granted equal sovereignty. It will not have to act surreptitiously; it will have to introduce itself and state its interest, indicate its war aims, specify its friends and its enemies - in short, say where it is, what allows it to distance itself from the others. In so doing, it will make visible to the others the territory that it occupies or that preoccupies it. (pp. 268-269)

Although this suggestion would otherwise conjure thoughts of a warm welcome by any particular discipline of knowledge within the academy, the practical realities of disciplinary knowledges, methods, histories and archives rather indicate limitations to such overlap, trespassing and efforts aimed at consilience. What passes as a proper methodology in one discipline, for example, may appear to contradict that of another, leaving an impasse between groups and persons that appears as insurmountable. The received wisdom of a given tradition becomes entrenched and frequently dogmatic, denying even the best intentioned interdisciplinary perspectives.

9.His comments are shared in this regard with those of climate scientists and politicians who have argued for a wider opening of political forms of representation within contemporary democratic contexts. See, amongst others, Purdy (2018), where the author argues for expanding democracy to include other non-human actors, citing Latour's work explicitly in favour of such a position. 
What Latour (2017:272) would rather work towards articulating, however, is a refocusing of interest and insight on the 'several overlapping authorities' that exist in reality, for no domain is an isolated island unto itself. The complexities of existence dictate that this be so. Each discipline, if perceived from another angle, is already invested in other methods, knowledges, tactics, opinions and imprecise, and even concealed, relationships. Learning to see more of this complexity and relationship should be the main occupation of education, though the preservation of a dominant narrative that provided by Homo sapiens has rather taken centre stage for far too long. What becomes of education in the century to come, on the other hand, depends very much on our ability to adapt to this new way of seeing the complexity and interdependence of reality.

In very practical terms, Latour recognises that any particular focal point - such as say, the sociological, economic, religious or biological - cannot expect to master the techniques and insights of every other domain, allowing rather for various fictional representations to replace more precise accounts until a later, more precise reckoning can be made. That's why Latour (2017:273) claims that, in a Parliament of Things, there will be a need for the fiction of representation for those things that cannot speak for themselves, such as water and air, but this is a fiction comparable to the fiction of the sovereign that Hobbes had once imagined in his Leviathan. His formulation of the concept of Gaia is accordingly that it is not something needed to replace the sovereignty of nation states, or to represent the Earth as ultimately sovereign over humanity; it is needed in order to demand that sovereignty be shared and not held in the possession of one particular agent (Latour 2017:280).

\section{Implications}

At this point, it should be obvious, but also perhaps incredibly daunting, to realise the implications of Latour's suggestions for education today. As many others have suggested for some time now within pedagogical research, there is certainly the need to allow 'other' disciplinary methods and knowledges to overlap with and permeate each other, causing interdisciplinarity to thrive as the central principle of education, perhaps no longer beholden to traditional disciplinary boundaries as has been typically considered normative, though relying upon the various models of veridiction associated with each at the same time. Educators must allow new linkages of varied knowledges to ripple outwards into other modes of existence, with one impacting the other, such as frequently occurs between politics and law, for example.

But such interactions are truly only the tip of the iceberg, as such activity also means allowing new 'non-academic' voices into the academy, even allowing non-human actors into the laboratory of the humans as subjects in their own right, no longer as non-human 'things' denied the rights to their own existence. As one of Latour's commentators, Miller (2013:63), has put it: 'Nature cannot be neatly separated from society and the human cannot be neatly distinguished from the nonhuman', a conclusion with drastic effects upon learning on the whole. In a time where climate change scientists need to have their voices heard more clearly than ever, it is imperative that we too learn to transgress traditional boundaries and let non-human actors be part of academic and political conversations in ways that allow us to creatively rethink the very nature of education from the ground up.

In particular, and in a way that shares with ecofeminist thought (and even ecofeminist theologians), Latour is attentive to the ways in which such reconfigurations of our most basic educational norms (like the division between the sciences and the humanities) can only come about through a critique of those modern forms of sovereignty that have sustained disciplinary boundaries and territories. His focus on the plurality of various modes of existence is a direct challenge to monolithic notions of sovereignty and autonomy that resonates with ongoing work in political theory and political theology. In other words, pedagogical reform will only be possible, from Latour's point of view, once we learn to take seriously the historically weddedness of humanity to its religious, political, economic and philosophical legacies. It is only by addressing the social and political complexities of the human being and its historical dominance over nature - as manifested in each of these various disciplines - that we might begin to reformulate educational norms in such a way as to open up the disciplines much wider towards other non-human participants.

\section{Acknowledgements Competing interests}

The author has declared that no competing interests exist.

\section{Authors' contributions}

I declare that I am the sole author of this research article.

\section{Ethical consideration}

This article followed all ethical standards for a research without direct contact with human or animal subjects.

\section{Funding}

This research received no specific grant from any funding agency in the public, commercial or not-for-profit sectors.

\section{Data availability statement}

Data sharing is not applicable to this article as no new data were created or analysed in this study.

\section{Disclaimer}

The views and opinions expressed in this article are those of the author and do not reflect the official policy or position of any affiliated agency of the author. 


\section{References}

Agamben, G., 2004, The open: Man and animal, transl. K. Attell, Stanford University Press, Stanford.

Anderson, P., 2017, The antinomies of Antonio Gramsci, Verso, London.

Derrida, J., 2008, The animal that therefore I am, M.-L. Mallet (ed.), transl. D. Wills, Fordham University Press, New York.

Felski, R., 2016, 'Introduction', New Literary History 47(2/3), 215-229. https://doi. org/10.1353/nlh.2016.0010

Geroulanos, S., 2010, An atheism that is not humanist emerges in French thought, Stanford University Press, Stanford, CA.

Hägglund, M., 2019, This life: Secular faith and spiritual freedom, Pantheon, New York.

Keller, C., 2018, Political theology of the earth: Our planetary emergency and the struggle for a new public, Columbia University Press, New York.

Latour, B., 1993, We have never been modern, transl. C. Porter, Harvard University Press, Cambridge.

Latour, B., 2013a, Rejoicing: Or the torments of religious speech, transl. J. Rose, Polity Cambridge.

Latour, B., 2013b, An inquiry into modes of existence: An anthropology of the moderns, transl. C. Porter, Harvard University Press, Cambridge.
Latour, B., 2017, Facing Gaia: Eight lectures on the new climatic regime, transl. C. Porter, Polity, Cambridge.

Latour, B., 2018, Down to earth: Politics in the new climatic regime, transl. C. Porter, Polity, Cambridge.

Miller, A.S., 2013, Speculative Grace: Bruno Latour and object-oriented theology, Fordham University Press, New York.

Northcott, M.S., 2013, A political theology of climate change, Eerdmans, Grand Rapids, Ml.

Powers, R., 2018, The overstory, W.W. Norton, New York.

Purdy, J., 2018, After nature: A politics for the anthropocene, Harvard University Press, Cambridge.

Ricoeur, P., 1995, Oneself as another, transl. K. Blamey, University of Chicago Press, Chicago, IL.

Sloterdijk, P., 2016, Spheres, vol. 3, Foams: Plural spherology, p. 460, transl. W. Hoban, Semiotext(e), South Pasadena, CA.

Touya de Marenne, E., 2016, The case for the humanities: Pedagogy, polity, interdisciplinarity, Rowman \& Littlefield, London.

Weisman, A., 2007, The world without us, Picador, New York.

Wood, D., 2005, The step back: Ethics and politics after deconstruction, SUNY Press, Albany, NY.

Wood, D., 2019, Reoccupy earth: Notes toward an other beginning, Fordham University Press, New York. 